\title{
Comment on "Short-term effects of relaxation music on patients suffering from primary open-angle glaucoma"
}

This article was published in the following Dove Press journal:

Clinical Ophthalmology

II December 2015

Number of times this article has been viewed

\author{
Abdullah Kaya' \\ Yakup Aksoy ${ }^{2}$ \\ Mehmet Koray Sevinç 3 \\ Oktay Diner ${ }^{4}$ \\ 'Department of Ophthalmology, \\ Anıttepe Military Dispansery, \\ Ankara, Turkey; ${ }^{2}$ Department of \\ Ophthalmology, Girne Military \\ Hospital, Girne, Cyprus; ${ }^{3}$ Department \\ of Ophthalmology, Beytepe Military \\ Hospital, Ankara, ${ }^{4}$ Department of \\ Ophthalmology, Erzurum Military \\ Hospital, Erzurum, Turkey
}

\section{Dear editor}

We read the current study "Short-term effects of relaxation music on patients suffering from primary open-angle glaucoma" by Bertelmann and Strempel, with great interest. ${ }^{1}$ The authors investigated if relaxation music had a positive effect on glaucoma. We congratulate the authors for this innovative study and want to make some contributions that may widen the impression area of this study.

In this study, relaxation music showed to decrease intraocular pressure (IOP) in glaucoma patients, while there was no decrease in the healthy control group. This finding indicates that psychological background can influence glaucoma. The relationship of Type A personality with some diseases has been known about for quite some time. Type A personality is characterized by an aggressive nature, a competitive drive, a sense of urgency, and a hostile temperament. Individuals who carry this kind of personality have been shown to have an increased risk of coronary heart disease, peptic ulcer, and central serous chorioretinopathy. ${ }^{2-4}$ Bubella et al also showed that a high amount of glaucoma patients have Type A behavior. ${ }^{5}$

We believe that evaluating IOP change after listening to relaxation music is a good method of identifying if psychologic background can influence glaucoma. Patients with Type A personality are expected to be more anxious. Thus, these patients may react much more to relaxation music. With this in mind, we wonder if a higher amount of glaucoma patients in this study have a Type A personality. If authors can correspond with patients in future studies, they could identify the amount of glaucoma patients who have a Type A personality through a questionnaire. We also wonder if a decrease in IOP is higher in glaucoma patients who have a Type A personality than patients who have not.

\section{Disclosure}

The authors report no conflicts of interest in this communication.

\section{References}

1. Bertelmann T, Strempel I. Short-term effects of relaxation music on patients suffering from primary open-angle glaucoma. Clin Ophthalmol. 2015;9:1981-1988.

2. Petticrew MP, Lee K, McKee M. Type A behavior pattern and coronary heart disease: Philip Morris's "crown jewel". Am J Public Health. 2012;102(11):2018-2025.

3. Catipović-Veselica K, Mićunović N, Ilakovac V, Catipović B, Mujić N, Lauc A. Emotion profile and behaviour pattern of patients with active duodenal ulcer compared with acute coronary patients. Acta Med Croatica. 1993;47(2):89-92. 
4. Yannuzzi LA. Type A behavior and central serous chorioretinopathy. Trans Am Ophthalmol Soc. 1986;84:799-845.
5. Bubella RM, Bubella DM, Cillino S. Type A behavior pattern: is it a risk factor for open-angle chronic glaucoma? J Glaucoma. 2014;23(4):199-201. 


\section{Authors' reply \\ Thomas Bertelmann \\ Ilse Strempel}

Department of Ophthalmology, Philipps-University Marburg, Baldingerstraße, Marburg, Germany

Correspondence: Thomas Bertelmann

Department of Ophthalmology, Philipps-Universität Marburg,

Baldingerstraße, 35033 Marburg, Germany

Email thomas.bertelmann@staff.uni-marburg.de

\section{Dear editor}

We would like to thank Kaya et al for their comments on our recent publication entitled "Short-term effects of relaxation music on patients suffering from primary open-angle glaucoma", which we read with keen interest. We absolutely agree with the thoughts expressed about glaucoma patients with Type A personality. We suggest creating a survey in regards to patients' personality type for any upcoming study within this field of research. It will be interesting to figure out if these patients may have an additional benefit from various relaxation techniques on IOP measurements.

\section{Disclosure}

Thomas Bertelmann is a medical advisor at Novartis Pharma GmbH, Nuremberg, Germany and scientific staff of Philipps-University Marburg, Department of Ophthalmology, Marburg, Germany. The authors report no other conflicts of interest in this communication.

Dove Medical Press encourages responsible, free and frank academic debate. The content of the Clinical Ophthalmology 'letters to the editor' section does not necessarily represent the views of Dove Medical Press, its officers, agents, employees, related entities or the Clinical Ophthalmology editors. While all reasonable steps have been taken to confirm the content of each letter, Dove Medical Press accepts no liability in respect of the content of any letter, nor is it responsible for the content and accuracy of any letter to the editor.

\section{Publish your work in this journal}

Clinical Ophthalmology is an international, peer-reviewed journal covering all subspecialties within ophthalmology. Key topics include: Optometry; Visual science; Pharmacology and drug therapy in eye diseases; Basic Sciences; Primary and Secondary eye care; Patient Safety and Quality of Care Improvements. This journal is indexed on

Submit your manuscript here: http://www.dovepress.com/clinical-ophthalmology-journal
PubMed Central and CAS, and is the official journal of The Society of Clinical Ophthalmology (SCO). The manuscript management system is completely online and includes a very quick and fair peer-review system, which is all easy to use. Visit http://www.dovepress.com/ testimonials.php to read real quotes from published authors. 